\title{
Inactivation of Scytalidium lignicolum Acid Protease B with 1,2-Epoxy-3-(4'-azido-2'-nitrophenoxy)propane ${ }^{\dagger}$
}

\author{
Daisuke Tsuru, Akihiko NaOtsuka, Ryuji Kobayashi, \\ Tadashi Yoshimoto, Kohei ODA* \\ and Sawao MUrao** \\ School of Pharmaceutical Sciences, Nagasaki University, \\ Bunkyo-machi, Nagasaki 852, Japan \\ * University of Osaka Prefecture, Mozuume-cho, Sakai, \\ Osaka 591, Japan \\ ** Kumamoto Institute of Technology, Ikeda-cho \\ Kumamoto 860, Japan \\ Received May 18, 1989
}

\begin{abstract}
The acid protease B of Scytalidium lignicolum (SAB) was modified with 1,2-epoxy-3-(4'-azido2 '-nitrophenoxy)propane [EANP] under acidic conditions. EANP was incorporated stoichiometrically into SAB, and the enzyme was almost completely inactivated. The modified enzyme was digested with thermolysin and EANP-labeled peptides were separated by high performance liquid chromatography (HPLC). The amino acid sequence of the major peptide labeled was Ile-Leu-Glu-Thr-Gly, which corresponds to the sequence of residue Nos. $51 \sim 55$ of the enzyme. Treatment of the peptide with $0.5 \mathrm{~N}$ hydroxylamine ( $\mathrm{pH}$ 10.5) resulted in the complete removal of the modifier from the labeled peptide, suggesting that EANP is ester-linked to the Glu-53 residue of the enzyme. The amino acid sequence (-Cys-GIn-Thr-Ala-Ile-Leu-Glu-Thr-Gly-) around Glu-53 of SAB shows high homology with those around the active site aspartic acids of calf chymosin and porcine pepsin. The results indicate the involvement of Glu-53 in the enzyme reaction of SAB.
\end{abstract}

Acid proteases, now called aspartic proteases, are known to be commonly inhibited by pepstatin, S-PI, diazoacetyl-DL-norleucine methylester (DAN), and 1,2-epoxy-3-( p-nitrophenoxy) propane (EPNP). Recently, however, some of acid proteases produced by bacteria, ${ }^{1 \sim 4)}$ fungi, ${ }^{5 \sim 7)}$ and Basidiomycetes ${ }^{8 \sim 10)}$ were shown to be insensitive to pepstatin and DAN. Among them, the acid protease B from Scytalidium lignicolum (SAB) has been reported to be inhibited by $\mathrm{EPNP}^{6)}$ and we have established the complete primary structure of the enzyme ${ }^{11}$ and found that glutamic acid-53 (Glu-53) of the enzyme is modified by EPNP with a concomitant loss of the ac- tivity. $^{12,13)}$

To confirm this result and to survey whether or not one more acidic amino acid residue is also related to the enzyme activity, we synthesized several diazo- and azido- compounds and examined their inhibitory effect on SAB. One of the diazo compounds tested, 1-diazo3-phenyl-2-propanone (DPP), was found to inhibit the enzyme through the modification of Asp-98 of $\mathrm{SAB}^{14)}$ and also one of the azido compounds, 1,2-epoxy-3-(4'-azido-2'-nitrophenoxy)propane $[\mathrm{EANP}]$, to react with the Glu-53, resulting in the inactivation of the enzyme activity. This report deals with the inactivation of $S$. lignicolum acid protease B by

† This work was supported in part by a Grant-in-Aid from the Japan Foundation of Applied Enzymology.

Abbreviations: EANP, 1,2-epoxy-3-(4'-azido-2'-nitrophenoxy)propane; EANP-OH, 1,2-dihydroxy-3-(4'-azido-2'nitrophenoxy)propane; S-PI, Streptomyces pepsin inhibitor (acetyl-pepstatin); DAN, diazoacetyl-DL-norleucine methylester; EPNP, 1,2-epoxy-3-(p-nitrophenoxy)propane; DPP, 1-diazo-3-phenyl-2-propanone; HPLC, high performance liquid chromatography; TFA, trifluoroacetic acid; PTH-, phenylthiohydantoin. 
EANP and the identification of the EANPreactive residue of the enzyme.

\section{Materials and Methods}

Materials. The acid protease B (SAB) was purified by the method of Murao et al. ${ }^{6)}$ with some modifications. 4Amino-2-nitrophenol and epichlorohydrin were purchased from Nakarai Kagaku Co., Kyoto. EANP was prepared by the method of Hixson et al. ${ }^{15)}$ with a slight modification; $\mathrm{mp} 97.5 \sim 98.5^{\circ} \mathrm{C}$; Elemental analysis, Caled for $\mathrm{C}_{9} \mathrm{H}_{8} \mathrm{O}_{4} \mathrm{~N}_{4}$ : C 45.76, H 3.41, N 23.72; Found: C 45.75, H 3.46, N 23.32. Purity was confirmed by NMR data. 1,2Dihydroxy-3-(4'-azido-2'-nitrophenoxy) propane [EANP$\mathrm{OH}]$, a hydrolysate of EANP, was prepared by treating EANP with $5 \mathrm{~mm}$ citric acid at $45^{\circ} \mathrm{C}$ for $12 \mathrm{hr}$.

Assay of proteolytic activity. The protease activity was assayed by the casein-Folin method. To $3 \mathrm{ml}$ of $1.3 \%$ Hammarsten casein (Merck) solution in $20 \mathrm{~mm}$ lactate buffer $(\mathrm{pH} 2.3), 1 \mathrm{ml}$ of enzyme solution was added at $37^{\circ} \mathrm{C}$. After incubation for $10 \mathrm{~min}$, the reaction was stopped by the addition of $4 \mathrm{ml}$ of $0.44 \mathrm{M}$ trichloroacetic acid (TCA). The mixture was kept at $37^{\circ} \mathrm{C}$ for $20 \mathrm{~min}$ and then filtered. One $\mathrm{ml}$ of the filtrate was mixed with $5 \mathrm{ml}$ of $0.44 \mathrm{M} \mathrm{Na}_{2} \mathrm{CO}_{3}$ and $1 \mathrm{ml}$ of 3-fold diluted Folin solution. After incubation at $37^{\circ} \mathrm{C}$ for $20 \mathrm{~min}$, the absorbance at $660 \mathrm{~nm}$ was measured. One unit was defined as the enzyme activity which liberates TCA-soluble products equivalent to $1 \mu \mathrm{g}$ tyrosine per min under these conditions. The protein concentration was estimated by assuming that $E_{1 \%, 1 \mathrm{~cm}}$ at $280 \mathrm{~nm}$ of $\mathrm{SAB}$ is $\left.15.8^{6}{ }^{6}\right)$

Inhibition studies. Enzyme $(0.17 \%)$ dissolved in $1 \mathrm{ml}$ of $0.1 \mathrm{M}$ sodium acetate buffer of various $\mathrm{pHs}$ was mixed with $1 \mathrm{ml}$ of EANP (a 100-fold molar excess over enzyme) suspended in the same buffer under gentle stirring at $30^{\circ} \mathrm{C}$ in the dark or light. Aliquots of the reaction mixture were periodically removed and the residual activities were assayed.

Modification of $S A B$ with EANP. SAB (7 mg) dissolved in $4 \mathrm{ml}$ of $10 \mathrm{~mm}$ sodium acetate buffer ( $\mathrm{pH} 3.4$ ) was mixed with a suspension of EANP as above. After $48 \mathrm{hr}$, the reaction mixture was dialyzed against three changes of 11

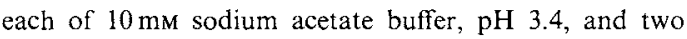
changes of 11 of $0.1 \mathrm{~m}$ sodium acetate ( $\mathrm{pH} 6.5$ ) containing $10 \mathrm{mM} \mathrm{CaCl}_{2}$ at $4{ }^{\circ} \mathrm{C}$ every $3 \mathrm{hr}$ to remove excess reagents.

The content of the modifier incorporated into the enzyme was calculated from molar absorption coefficients of EANP-OH and SAB. EANP-OH has maximum absorptions at $251 \mathrm{~nm}$ and $365 \mathrm{~nm}$, and the molar absorption coefficients were experimentally estimated to be $19,500 \mathrm{M}^{-1}, \mathrm{~cm}^{-1}$ at $251 \mathrm{~nm}, 4,890 \mathrm{M}^{-1}, \mathrm{~cm}^{-1}$ at $280 \mathrm{~nm}$, and $2,110 \mathrm{M}^{-1}, \mathrm{~cm}^{-1}$ at $365 \mathrm{~nm}$. The molar absorption coefficient of SAB at $280 \mathrm{~nm}$ was reported to be
$34,700 \mathrm{M}^{-1}, \mathrm{~cm}^{-1}$ and that at $251 \mathrm{~nm}$ was experimentally found to be $16,330 \mathrm{M}^{-1}, \mathrm{~cm}^{-1}$

Proteolytic digestion of EANP-modified $S A B$ and the separation of peptides. EANP-modified $\mathrm{SAB}(6 \mathrm{mg})$ was digested with thermolysin $(50 \mu \mathrm{g})$ at $37^{\circ} \mathrm{C}$ for $3.5 \mathrm{hr}$ in $1 \mathrm{ml}$ of $0.1 \mathrm{~m}$ sodium acetate buffer, $\mathrm{pH} 6.5$, containing $10 \mathrm{~mm}$ $\mathrm{CaCl}_{2}$. Samples of the digest were put on a reverse phase HPLC column (Vydac C18: $4.6 \times 250 \mathrm{~mm}, 5 \mu \mathrm{m}$ ) equilibrated with $0.075 \%$ trifluoroacetic acid (TFA) in water and eluted with an increasing gradient of organic solvent (acetonitrile-2-propanol: $3: 1, \mathrm{v} / \mathrm{v}$ ) containing $0.06 \%$ TFA $(0 \sim 40 \%$ for $60 \mathrm{~min}$, then $40 \sim 70 \%$ for $10 \mathrm{~min})$ at a flow rate of $1.0 \mathrm{ml} / \mathrm{min}$ and $25^{\circ} \mathrm{C}$. The elution of peptides was monitored by following absorbances at $214 \mathrm{~nm}$ and $365 \mathrm{~nm}$.

Removal of modifier from EANP-labeled peptide. The peptide labeled with EANP was incubated with $0.5 \mathrm{~N}$ hydroxylamine $(\mathrm{pH} 10.5)$ at $37^{\circ} \mathrm{C}$ for $24 \mathrm{hr}$ and the reaction mixture was used for HPLC.

Sequencing of amino acids of EANP-labeled peptide. The peptide was purified by HPLC to homogeneity and its amino acid sequence was found by manual Edman degradation by the method of Kobayashi and Tarr. ${ }^{16)}$ The amino acid composition was determined by the phenylthiocarbamyl-amino acid method. ${ }^{17 .}{ }^{181}$

\section{Results and Discussion}

\section{Inactivation of $S A B$ by EANP}

Figure 1 shows activity changes of the enzyme caused by incubation with EANP at various pHs, and Fig. 2 illustrates analysis of

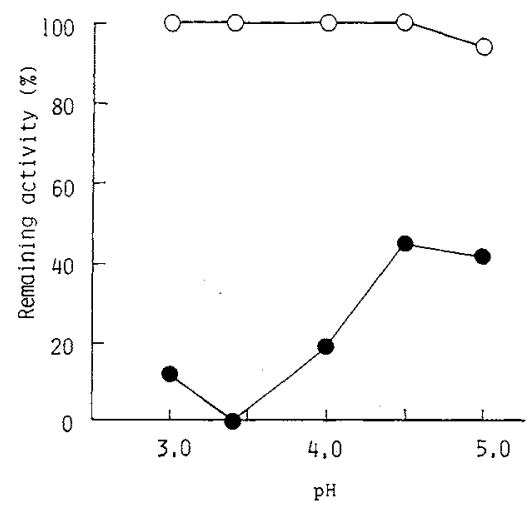

Fig. 1. Effects of $\mathrm{pH}$ on the Inhibitory Activity of EANP for the Enzyme.

The enzyme was incubated at $30^{\circ} \mathrm{C}$ for $72 \mathrm{hr}$ with $(--)$ or without EANP (-O--) in the dark. The other conditions are described in the text. 
the course of enzyme inactivation by EANP in the presence and absence of casein. The maximum inactivation was observed at $\mathrm{pH} 3.4$ and the presence of substrate effectively prevented the inactivation. This result suggests that EANP reacts at or near the substratebinding site of the enzyme.

Incubation of $\mathrm{SAB}$ with $\mathrm{EANP}$ at $30^{\circ} \mathrm{C}$ for

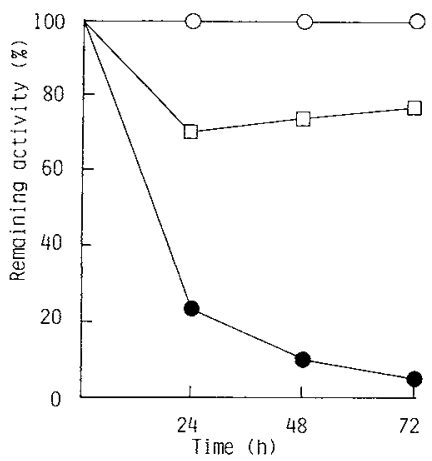

Fig. 2. Activity Changes of the Enzyme upon Incubation with EANP in the Presence and Absence of Casein.

The enzyme was incubated with EANP at $30^{\circ} \mathrm{C}$ and $\mathrm{pH}$ 3.4. The concentration of casein was $0.5 \%$. See the text for experimental details.

- - , without EANP; - - - with EANP; - $\square-$, with EANP and casein.

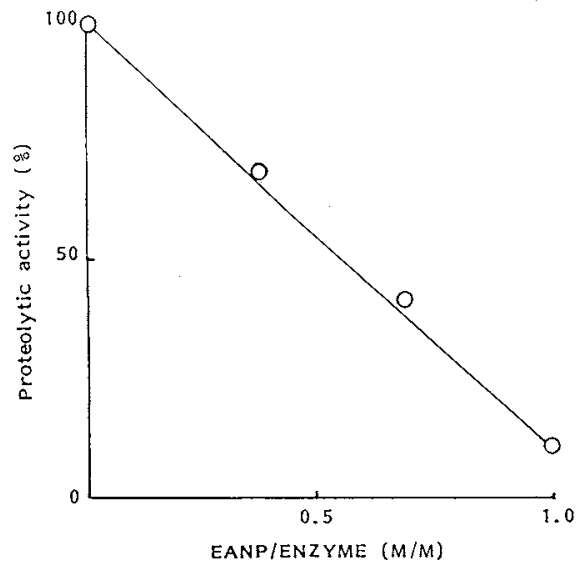

Fig. 3. Correlation of Activity Change with Binding Ratio of EANP to the Enzyme.

The enzyme was incubated with a 100 -fold molar excess of EANP at $\mathrm{pH} 3.4$ and $30^{\circ} \mathrm{C}$. To analyze the activity change and the extent of EANP-incorporation into the enzyme, aliquots of the reaction mixture were periodically withdrawn, and after removal of excess reagents, the remaining activities and the binding ratio of EANP to the enzyme were assayed.
$48 \mathrm{hr}$ resulted in $90 \%$ loss of the original activity, and the numbers of EANP bound per mole of SAB were calculated to be 0.95 . As shown in Fig. 3, there was observed a linear correlation between the numbers of EANP bound per mole of SAB and the degree of the enzyme inactivation and stoichiometric binding of EANP to the enzyme.

\section{Identification of EANP-reactive amino acid res- idue in $S A B$}

The EANP-modified SAB was digested with thermolysin and the resultant peptides were separated by HPLC. The elution profile of the thermolysin digest is shown in Fig. 4. Three peaks showing absorbance at $365 \mathrm{~nm}, \mathrm{~S} 1, \mathrm{~S} 2$, and S3, were observed. They were pooled and

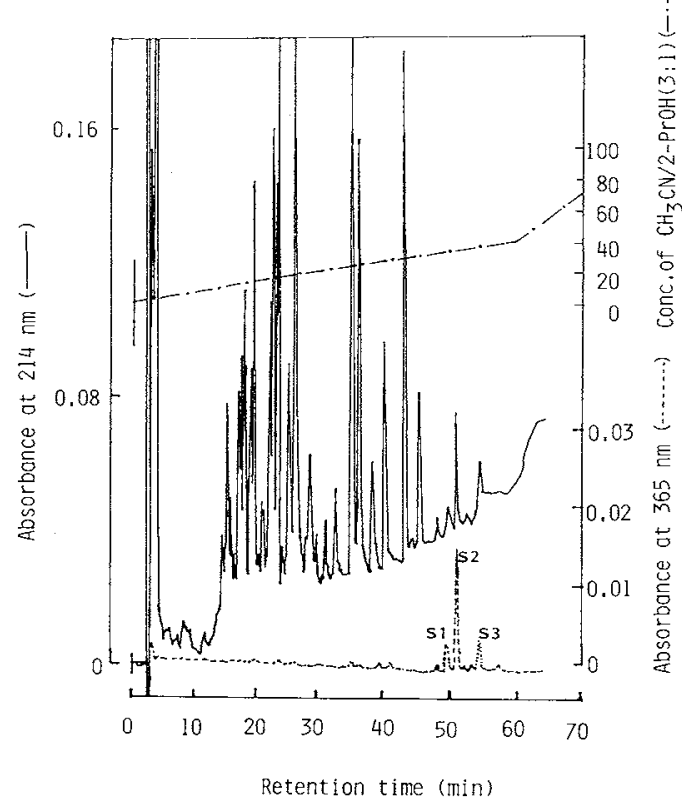

Fig. 4. HPLC Pattern of Thermolysin-digest of EANPmodified Enzyme

See the text for experimental details.

Table I. Amino ACid SEQuence of EANP-LABeled Peptides

\begin{tabular}{ccc}
\hline Peptide & Amino acid sequence & Yield $(\%)$ \\
\hline S2 & Ile-Leu-Glu-Thr-Gly & 30 \\
S3 & Ile-Leu-Glu-Thr-Gly & 3 \\
\hline
\end{tabular}


purified by HPLC to homogeneity.

The analytical data of the EANP-labeled peptides, S2 and S3, are shown in Table I. The amino acid sequence of peptide $\mathrm{S} 2$ was IleLeu-Glu-Thr-Gly, which corresponds to the sequence of residue Nos. $51 \sim 55$ of $\mathrm{SAB}$, and $\mathrm{S} 3$ peptide had the same sequence as that of $\mathrm{S} 2$, though the yield was quite low. The reason why the retention time is different between the two peptides is unknown. The amount of S1 was too small to establish its amino acid sequence. The glutamic acid residue in $\mathrm{S} 2$ will be No. 53 of SAB, which has previously been reported to be the EPNP-reactive site in SAB. ${ }^{12,131}$

\section{Removal of modifier from EANP-labeled pep- tide}

If EANP is ester-linked to a carboxyl group of an acidic amino acid residue in $\mathrm{SAB}$, the modifier is expected to be released from the peptide by alkali treatment. To examine this possibility, S2 peptide was incubated with $0.5 \mathrm{~N}$ hydroxylamine $(\mathrm{pH} 10.5)$ at $37^{\circ} \mathrm{C}$ for $24 \mathrm{hr}$, and HPLC patterns before and after alkali treatment were compared. As shown in Fig. 5, peak S2 disappeared, as monitored by absorbance at $365 \mathrm{~nm}$ after alkali treatment while another peak, S2A, appeared. This fraction contained neither amino acid nor peptide, and its retention time, $40 \mathrm{~min}$, exactly coincided with that of EANP-OH, a hydrolysate of EANP.

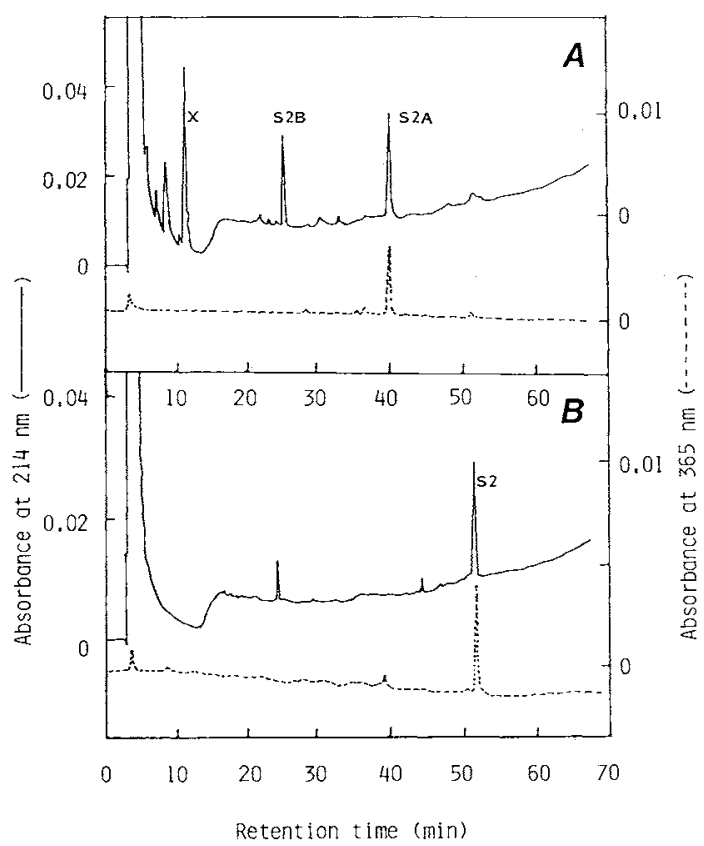

Fig. 5. HPLC Profiles of EANP-labeled Peptide before and after Treatment with $0.5 \mathrm{~N}$ Hydroxylamine.

About $23 \mu \mathrm{g}$ of peptide was chromatographed by HPLC under the same conditions as in Fig. 4. The other conditions are described in the text. A and B indicate the profiles after and before alkali treatment. $\mathrm{X}$, hydroxylamine.

\begin{tabular}{|c|c|c|}
\hline Enzyme & Anino acid sequence & References \\
\hline & 53 & \\
\hline Acid protease $B$ & -Cys-GIn-Thr-hla-Mle-Lev-Glu-Thr-Gly-Phe- & \\
\hline of $\underline{\text { S. }}$ lignicolum & 215 & \\
\hline Calf chymosin & 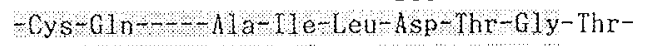 & 19 \\
\hline Porcine pepsin & $-0 y s-\mathrm{dln}---\rightarrow 1 \mathrm{a}-\mathrm{Ml}-\mathrm{VaI}-\mathrm{Asp}-\mathrm{Thr}-\mathrm{GI}$-Thr- & 19 \\
\hline Penicillopepsin & ---- Ser----Gly-Ale-Ala-Asp-Thr-Gly-Thr- & 20 \\
\hline Rhizopuspepsin & -Ser-Phe-Asp-GIy-I le-Leu-Asp-Thr-Gly-Thr- & 21,22 \\
\hline $\begin{array}{l}\text { Acid protease } B \\
\text { of } S \text {. Iignicolum }\end{array}$ & -Thr-Ser-1sp-Thr-Ser-G1y-Ser-Ala-Thr-Leu- & \\
\hline Calf chymosin & -Leu-Phe-Asp-Thr---Gly-Ser-Ser-Asp-Leu- & 19 \\
\hline Porcine pepsin & - Ile-Phe-Asp-Thr---Gly-Ser-Ser-Asn-leu- & 19 \\
\hline Penicillopepsin & -Asn-Phe-Asp-Thr-- Gly-Ser-Ser-Asp-Phe- & 20 \\
\hline Rhizopuspepsin & $-A s p-P h e-A s p-T h r---$ - Gly-Ser-Ala-Asp-Leu- & 21,22 \\
\hline
\end{tabular}

Fig. 6. Comparison of Amino Acid Sequences around Glu-53 and Asp-98 of Scytalidium lignicolum Acid Protease B with Those of Active Site Aspartic Acid Residues of Some Other Pepstatin-sensitive Acid Proteases. 
Another peak, S2B, which appeared after alkali treatment, showed an amino acid composition of Ile, Leu, Glu, Thr, and Gly in an equimolar ratio, indicating that it was derived from Peak $\mathrm{S} 2$. These results show that the dissociation of the modifier from $\mathrm{S} 2$ takes place by alkali treatment and that the binding of the modifier to the peptide is base-labile, presumably being an ester linkage between EANP and carboxyl group of acidic amino acid in peptide. Thus, Glu-53 may be one of the active site amino acid residues of $\mathrm{SAB}$, as we have suggested. ${ }^{12,13)}$

It has been reported that sequences around active site amino acids in acid proteases show high homology, regardless of their origins. ${ }^{19 \sim 22)}$ As shown in Fig. 6, a significant homology was observed between sequences around Glu-53 of SAB and the active site Asp215 of other acid proteases, except that Asp is replaced with Glu in $\mathrm{SAB}$.

In general, acid proteases have two aspartic acid residues participating in the catalytic reaction. ${ }^{19 \sim 22)}$ In the case of SAB, Asp-98 has been suggested to be another acidic amino acid involved in the enzyme activity, since a diazo compound, 1-diazo-3-phenyl-2-propanone (DPP), modifies this residue in the presence of cupric ions, accompanied by the complete loss in the activity of $\mathrm{SAB},{ }^{14)}$ and the amino acid sequence around Asp-98 of SAB is homologous to that of active site Asp-32 of other acid proteases (Fig. 6).

To confirm the participation of two acidic amino acids in the enzyme reaction of $\mathrm{SAB}$, we attempted to synthesize epoxide derivatives containing diazo or azido groups, which were expected to react as bifunctional reagents, and examined their inhibitory activity under various conditions: under illumination, at different $\mathrm{pHs}$ and in the presence or absence of cupric ions. EANP was found to be most inhibitory toward the enzyme under the conditions shown in Figs. 1 and 2. Contrary to our expectation, however, EANP was reactive only with Glu-53.

In the case of pepsin, Asp-32 is supposed to be ionized and Asp-215 to be in a protonated form for its activity. ${ }^{23 .}{ }^{24)}$ Hence, Asp-215 is reactive to DAN (diazo-reactive) and Asp-32 is reactive to EPNP (epoxide-reactive). In the case of $\mathrm{SAB}$, however, the amino acid sequence around Glu-53, which is reactive to EANP as well as EPNP (epoxide-reactive), is more homologous to that around Asp-215 (diazo-reactive) than to the sequence around Asp-32 (epoxide-reactive) of pepsin. Furthermore, the amino acid sequence around Asp-98, which is reactive to DPP (diazoreactive), is more homologous to that of epoxide-reactive Asp-32 of pepsin. It remains to be clarified by further experiments whether such diversity is responsible to the differences in properties such as sensitivity to inhibitors and substrate specificity between $\mathrm{SAB}$ and other pepstatin-sensitive acid proteases.

From these results and previous ones, we conclude that two acidic amino acids, Glu-53 and Asp-98, participate in the enzyme activity of SAB, unlike pepstatin-sensitive acid proteases, in which two aspartic acid residues are involved in their catalytic reaction.

Acknowledgments. The authors are grateful to Mr. E. Takahashi and Misses R. Eguchi and K. Kurazono for their assistance in this experiment.

\section{References}

1) K. Oda, M. Sugitani, K. Fukuhara and S. Murao, Biochim. Biophys. Acta, 923, 463 (1987).

2) K. Oda, T. Nakazima, T. Teranishi, K. Suzuki and S. Murao, Agric. Biol. Chem., 51, 3073 (1987).

3) S. Murao, J. Appl. Enzymol. Assoc., 22, I (1987).

4) S. Murao, K. Ohnishi, M. Nagao, K. Oda and T. Shin, Agric. Biol. Chem., 52, 1629 (1988).

5) S. Murao, K. Oda and Y. Matsushita, Agric. Biol. Chem., 36, 1647 (1972).

6) S. Oda and S. Murao, Agric. Biol. Chem., 38, 2435 (1974).

7) W. H. Chang, S. Horiuchi, K. Takahashi, M. Yamasaki and Y. Yamada, J. Biochem., 80, 975 (1976).

8) T. Teranishi, K. Oda, M. Kono and S. Murao, Agric. Biol. Chem., 45, 1937 (1981).

9) T. Teranishi, K. Oda, M. Kono and S. Murao, Agric. Biol. Chem., 48, 1029 (1984)

10) H. Kobayashi, I. Kusakabe and M. Murakami, Agric. Biol. Chem., 49, 2395 (1985).

11) T. Maita, S. Nagata, G. Matsuda, S. Maruta, K. 
Oda, S. Murao and D. Tsuru, J. Biochem., 95, 465 (1984).

12) D. Tsuru, S. Shimada, S. Maruta, T. Yoshimoto, K. Oda, S. Murao, T. Miyata and S. Iwanaga, $J$. Biochem., 99, 1537 (1986).

13) D. Tsuru, "Peptides and Proteases," in Advances in Biosciences, Vol. 65, ed. by R. L. Schowen and A. Barth, Pergamon Press, Oxford and New York, 1987, pp. $257 \sim 262$.

14) D. Tsuru, R. Kobayashi, N. Nakagawa and T. Yoshimoto, Agric. Biol. Chem., 53, 1305 (1989).

15) S. H. Hixson, J. L. Hurwitz, K. J. Langridge, D. C. Nichols, K. M. Provost and A. M. Wolff, Biochem. Biophys. Res. Commun., 111, 630 (1983).

16) R. Kobayashi and G. E. Tarr, Proteins, Nucleic Acids and Enzymes, 31, 991 (1986).

17) D. R. Koop, E. T. Morgan, G. E. Tarr and M. J.
Coon, J. Biol. Chem., 257, 8472 (1982).

18) G. E. Tarr, in "Methods of Protein Microcharacterization," ed. by J. E. Shivery, Humana Press, Clifton, N.J., 1986, pp. 155 194.

19) B. Foltmann and V. B. Pedersen, "Acid Proteases," in Advances in Experimental Medicine and Biology, Vol. 95, ed. by J. Tang, Plenum Press, New York and London, 1977, pp. 3 22 .

20) L-H. Hsu, L. T. J. Delbaere, M. N. G. James and T. Hofmann, Nature, 266, 140 (1977).

21) K. Takahashi, J. Biol. Chem., 262, 1468 (1987).

22) R. Delaney, R. N. S. Wong, N-I. Wu and J. Tang, $J$. Biol. Chem., 262, 1461 (1987).

23) K. C. S. Chen and J. Tang, J. Biol. Chem., 247, 2566 (1972).

24) J. A. Hartsuck and J. Tang, J. Biol. Chem., 247, 2575 (1972). 